\title{
Accounting
}

\section{Board characteristics, ownership structures and firm R\&D intensity}

\author{
Te-Kuang Chou ${ }^{\mathrm{a}}$ and Lee-Anne Johennesse ${ }^{\mathrm{a}^{*}}$
}

${ }^{a}$ College of Business, Department of Finance, Southern Taiwan University of Science and Technology, (STUST), Taiwan

\begin{tabular}{l}
\hline C H R O N I C L E \\
\hline Article history: \\
Received: November 2, 2020 \\
Received in revised format: \\
November 27 2020 \\
Accepted: December 21, 2020 \\
Available online: \\
December 21, 2020 \\
\hline Keywords: \\
Board Characteristics \\
Ownership Structures \\
Strategic Decision Making \\
R\&D Intensity
\end{tabular}

\section{Introduction}

R\&D expenditure relating to innovation and capability development is a consequence attributable to corporate governance considerations such as ownership (Hoskisson et al., 2002) and board characteristics (Kor, 2006). Ensuing this paradigm, boards exert significant influence on firm strategic imperatives, including financial decision making - R\&D being a core component of this reasoning. The preeminence of agency theory continues to dominate corporate governance mechanisms, and the influence of the Board on R\&D spending is no exception. Contrasting opinions and conclusions have emerged in this regard. Agency theory was used to advocate that outside directors positively influence R\&D (Kor, 2006) as they are disposed to fulfill a supervisory position on intrinsically risk-averse managers and may circumvent R\&D expenditure, which they treat as precarious (Jensen and Meckling, 1976). Contradistinction exists, where agency theory postulates that outside directors impede R\&D expenditure by adopting financial controls, a consequence being targeting efficiency and decreasing R\&D spending (Baysinger \& Hoskisson, 1990). Extant literature, also suggests that outside directors are negatively (Deutsch, 2005) and non-significantly (Kor, 2006) correlated with R\&D expenditure. Furthermore, a premise exists, where outsiders are more prone to monitor agents than insiders, and these outsiders must follow the CEO, thus impacting their inclination to exert a controlling influence (Westphal, 1999). Conversely, inside directors, in their quest to circumvent self-interest accusations, are less reluctant to monitoring (Boyd, 1994).

\footnotetext{
* Corresponding author. Tel.: +886 0903129011

E-mail address: leeannej@stust.edu.tw (L.-A. Johennesse)

\begin{abstract}
This study explores the impact of board characteristics and ownership structures on the strategic observations of 434 technological firms listed on the Taiwanese Stock Exchange (TWSE) between 2014 and 2017. Contrary to extant research, the findings reveal that board independence plays a crucial thereon. Moreover, the empirical results demonstrate negative and significant relationships between CEO Duality, Board size (in big companies), Executive \& Manager, Board of Directors and Top results emerging from this Taiwanese contextual study support, and are consistent with the predictions of the 'entrenchment argument' and are counter to the 'convergence of interest' argument. The findings ing from this research provide an opportunity for further discussion and analysis regarding corporate governance principles and reg
\end{abstract}

(C) 2021 by the authors; licensee Growing Science, Canada 
Studies have reported the inclusion of internal and external director expertise and resources; which are significant factors impacting their impetus to act as monitoring agents.

These antithetical applications of agency theory therefore position further exploration, and analysis, of the influence of board characteristics on R\&D expenditure. Research dependence theory (RD theory) underscores the qualities of board capital, which contribute to the issuance of resources. The merits of this theory are persuasive; however, it is significant to consider the board's motivation to transfer these capabilities to the firm. Consequently, this provision of board capital impacts board functionality and this association is moderated by board independence (Hillman and Dalziel, 2003). Furthermore, related studies have reflected that this board capital considerably signals board contribution of strategy. Thus, the integration of RD theory and agency logic is usefully concerning management expertise, from an ownership perspective. Consequently, board capital, in terms of knowledge, experience and connections may signal motivation in responding to R\&D spending (Dalziel et al., 2011).

\section{Literature Review}

\subsection{Board Characteristics}

\subsection{CEO duality}

The combination of the CEO and Chairman of the Board positions has garnered much debate from researchers and scholars. This positional consolidation not only prejudices the effectiveness incumbent in the associative roles and responsibilities, but it also impacts the strategic decision making and board monitoring utilities (Fama \& Jensen, 1983; Jensen, 1993; Lehn \& Zhao, 2006). Duality also creates the impetus for board domination, and the opportunity to impede board independence and management discipline (Mallette and Fowler, 1992). Subsequently, CEO duality positions CEO's to simply defend the R\&D strategic projects that they favor, irrespective of shareholder interest requirements. After these dispositions, it is believed that the separation of CEO and Chairman of the board obligations is ideal for board independence augmentation and management opportunism limitation, thus expediting R\&D projects, which may result in superior future firm performance that encapsulates competitive and sustainable prospects.

\subsection{Board Size}

Using a resource theory perspective Pfeffer (1972) postulated that the number of directors on the board is influenced by the firm environmental factors, thus board size is a function of firm size. A large board offers variability of resources, such as skills, knowledge, experiences, and networked relationships, which may positively support R\&D initiatives, (Ashwin et al., 2016). Furthermore, large boards are less likely to be subject to management dispositions Zahra \& Pearce (1989). Larger boards with many independent directors may be more open to R\&D decision making. From a resource-based theoretical perspective, these boards can also support additional funding prospects to augment firm-level opportunities resulting from R\&D initiatives (Wang \& Hsu, 2013). However, a large board also exhibits some inherent barriers. These boards may be confronted by ineffectual participation, communication, and interaction paths, thus impeding decision-making efficiency. Moreover, these large boards may also be challenged to effectively monitor managers (Ashwin et al., 2016), and consequently being overpowered by CEO's, (Pathan \& Faff, 2013), resulting in R\&D under-investment. Furthermore, too many directors on a board may result in the 'free rider syndrome, ineffectiveness, and coordination expenses' (Jensen 1993). Therefore, the size of the board influences R\&D spending, indicative of a U-shaped relationship. Board demographic diversity and a resource-dependent perspective advocate that bigger boards equate to higher resource potential in terms of skills, knowledge, experience, funding, and networks. Agency theory, on the other hand, suggests that smaller groups are innately better positioned for enhanced monitor and control functionality, enhanced communication channels, and free-rider problem exemption (Platt \& Platt, 2012).

\subsection{Independent Directors}

Board independence has received increased focus as it is a significant feature of board composition and corporate governance. Companies with multiple-dependent board members are presumed to limit R\&D investment due to the risks associated with such projects and their resultant impact on firm value. Conversely, firms with independent boards are more open to augment and sustain their innovative proficiency as they are less risk-averse (Chen \& Hsu, 2009). Similarly, Ashwin et al. (2016) postulate that agency theory and resource-dependent theory forecast a positive relationship between independent board members and R\&D investment. Furthermore, companies' multiple independent board members are more disposed to promote an increase in R\&D investment. Outsiders may accept higher levels of risk if there are opportunities for cooperation to combine their expertise, skills, knowledge, and resources. The potential of this value is the advocacy of R\&D initiatives regardless of concomitant risks (Dalziel et al., 2011). Additionally, independent boards are thought of as more risk forbearing than dependent members because they holders of more firm shareholdings in the form of compensation packages; they can track valuable R\&D investments that are high risk (Hernandez et al., 2010, p. 154). Furthermore, independent board members are considered more objective than executive directors. The reason being that insider members are not disposed to critically analyze and monitor managers as they form part of this grouping. 
A consequence of this situation is the potential reinforcement of myopic behaviors, coupled with decreased effort and focus to pursue initiatives that have a long-term horizon. Therefore, the occurrence of more outside directors on the board can decrease this executive myopia, and boost active participation in firm strategic imperatives. Contra-wise, extant literature proposes, through empirical evidence that independent directors are negatively and non-significantly associated with R\&D investment (Kor, 2006, p. 1095). Furthermore, conflict of interest may result between outsider board members and the top management team predominantly due to power struggles. This situation may encumber R\&D strategy, as management will focus their attention and effort on preserving their authority rather than converging on this matter (Kor, 2006). Likewise, independent members may discourage R\&D spending since those members do not have appropriate and adequate knowledge, and rather place emphasis on control and monitoring, lowering costs, effectiveness, and performance outcomes (Dalziel et al., 2011). The supposition is that outsider board members monitor and control more robustly than insider members' control. Researchers suggest that dependent members can simply become morally obliged to managers in circumstances where social and psychological factors may bind their inclination to use controlling power (Dalziel et al.,2011). Linck et al. (2008) suggest that companies with increased growth opportunities, bigger R\&D expenditures, and high stock return volatility have smaller and less independent boards, while large firms have bigger and more independent boards. Osma (2008) proposed that the skills and expertise of independent directors may contrast the myopic management behavior that results in decreased R\&D investments, and could balance the conflict between owners and managers because they can authenticate the opportunistic restrictions implemented through the reduction in R\&D investments, and may boost investment in innovation. Dong and Gou (2010) suggested a positive relationship between the percentage of independents and R\&D, whereas Chen and Hsu (2009) reported that family ownership may discourage R\&D investments, independent directors diminishes such effects and contributes to an increase in R\&D investments. Their research also postulates that R\&D investments reveal higher expected cash flows and a lower cost of equity, particularly in firms with more independent directors on the board. $\mathrm{Lu}$ and Wang (2015) proposed a positive relationship between independent board directors and investment in R\&D and a negative relationship regarding physical assets. In contrast, some researchers provide empirical evidence that independent directors are negatively and non-significantly associated with R\&D investment (Dentsch, 2005, p. 437; Kor, 2006, p. 1095). They provide explanations that conflict of interest arises between outsider board members and the top management team, mainly because of the power struggle. This may hurt R\&D strategy, as management will put much effort into maintaining their authority, rather than focusing on working together (Kor, 2006, p. 1097). Furthermore, the study depicts that independent members may discourage R\&D spending since those members do not have sufficient knowledge about the firm but instead focus on control and monitoring, low cost, effectiveness, and performance outcome (Dalziel et al., 2011, p. 1237).

\subsection{Ownership structures}

Firm ownership structures are significant contributors to investment decision making, with specific emphasis on R\&D expenditure (Lee and O'Neil, 2003; Porter, 1990). There are conflicting results among researchers and practitioners. Positive relationships between large shareholders and R\&D investments have been recorded (Hosono et al., 2004; Wahal \& McConnell, 2000). Conversely, negative links have been reflected (Jones and Danbolt, 2003). Furthermore, nonaligned associations have also been demonstrated (Francis \& Smith, 1995; Holderness \& Sheehan, 1988).

\subsection{Financial Institutions}

Extant empirical studies have indicated that ownership by financial institutions is correlated to R\&D activities, however, the results have been indeterminate. Some results reflected that banks had no relationship to R\&D (Kochhar \& David, 1996), while others found a positive and significant correlation (Lee, 2005). Furthermore, Gugler (2003) demonstrated that bank-controlled firms are associated with low payout ratios, which are inversely related to R\&D investments. In line with these divergent conclusions, it is anticipated that financial institutions exhibit a negative influence on R\&D spending. The relationship between firms and banks extends beyond simple rights and includes loans and credit arrangements (Kroszner \& Strahan, 2001). This association aligns the credit and stakes of these conservative financial institutions to the potential insecurities of R\&D activities. Moreover, financial institution manifestation may catalyze firms to advance capital requirements via debt financing initiatives (Petersen \& Rajan, 1994). Increased debt proportions, resulting in increased debt risk associations, consequently influence the investment decision making of the firm. A related interpretation in the form of short-term investment bias is prevalent in this regard (Grinblatt \& Titman, 1998). Companies engage in strategic short-term initiatives as an endeavor to moderate debt obligations. Consequently, this partiality impedes R\&D investments, which are principally long-term oriented (Hoskisson et al., 1993). Accordingly, it is presumed that financial institutional ownership, depresses R\&D investment spending.

\subsection{Board of Directors Ownership}

Similar to board directors, and as a consequence of their inherent power, shareholders are significant influencers of R\&D activities. Their investment interests can be both protected and augmented pending value requirements (Hernandez et al., 2010). Researchers have demonstrated that ownership is fundamental for endorsing R\&D strategic decision making and spending. This is especially prevalent when board members have contributed their wealth by investing in company stock (Barker \& Mueller, 2002). Thus, boards that have stock holdings, are positioned as stewards to safeguard investments, by strategically authorizing projects, 
processes, and investments that may incur wealth maximization for all stockholders. Kor (2006) reported that there is a link between large shareholders who participate in firm decision making and increased levels of R\&D. This is a consequence of the differences relating to confidence levels, predispositions, and objectives between owners and managers. Board members holding substantial stock may be inclined to engage in projects deemed to be risky, by implementing decisions that may have negative implications on the firm and to harness increased personal returns (Platt \& Platt, 2012).

However, agency perspectives contend that board members holding firm stock, are not immune to decision making that may impede economic benefit attainment (Jensen, 1993). Furthermore, the risk preferences of shareholders may vary relative to managers. This is resultant from the shareholding diversification potential for shareholders, compared with the rewards and future associated benefits of managers who are bonded to the firm. Thus, any potential R\&D failures may significantly influence their prospects. Owners may campaign for increased risk engagement beyond the board's inclination. R\&D initiatives' intrinsic insecurity and complexity, coupled with long-run cycles, may lead to board risk aversion tendencies. Additionally, investors holding increased firm share portfolios may similarly depress R\&D activities perceived to be risk inherent. Thus, the board of director stock ownership may engender increased monitoring, as well as risk-taking prospects associated with future expected requirements. Conversely, risk aversion may drive these board members who are hesitant to engage in these R\&D projects due to the uncertain and complicated facets of these projects.

\subsection{Executives and Managers Ownership}

Agency theory suggests that CEO's require substantial at-risk wealth in strategic decisions to augment shareholder returns. Significant holdings in this regard is a mechanism of binding CEO wealth to shareholder wealth maximization (Jensen and Murphy, 1990). Furthermore, research indicates that CEO's with substantial holdings will invest in more precarious investments that exhibit potential economic benefit. Additionally, researchers have argued that CEOs with significant stockholdings will undertake more risky investments (May, 1995). As a consequence, agency theory intimates increased at-risk wealth predisposes top managers to be more long-term positioned. Conversely, managers with decreased holdings would apportion lower levels of R\&D. Risk and long-run payoffs of R\&D, positions CEOs exhibiting lower levels of at-risk wealth to be less inclined to undertake the investments.

\subsection{Block holders}

Ownership structures are a significant driver of investment policy, and consequently R\&D spending (Lee and O'Neill, 2003). Agency theory expects ownership concentration may diminish agency costs and support sufficient levels of R\&D investment because it limits management's inclination to track suboptimal strategies (Demsetz \& Lehn, 1985; Jensen \& Meckling, 1976). Institutional block holders may be in the form of non-financial (corporations), financial (banks, insurance/retirement/mutual funds), and non-institutional (individuals), (Kochhar \& David, 1996; Lee, 2005; Hoskisson et al., 2002). Extant literature demonstrates conflicting perspectives regarding the R\&D spending impact of ownership concentration. (Baysinger et al., 1991; Hill \& Snell, 1988; Hosono et al., 2004; Wahal \& McConnell, 2000), denoted a positive relationship. While (Francis and Smith, 1995; Graves, 1988; Holderness and Sheehan, 1988) found negative relationships. (Chung et al., 2003; Francis \& Smith, 1995), on the other hand, reported limited compelling impacts on R\&D.

\section{Methodology}

\subsection{Data and Sample}

The data utilized in this study was extracted from the Taiwan Economic Journal (TEJ) database. Employing a sample comprising 1736 firm-year observations of 434 technological firms listed on the Taiwanese Stock Exchange (TWSE) between 2014 and 2017 (4-year observations), we have conducted a regression analysis on a twofold basis. The first analysis comprises a full set of all the independent and dependent variables, and the second data set splits the sample into 3 models according to the control variables (Company growth rate, Company size, and Company leverage rates).

\subsection{Multivariate regression clarifications}

$Y_{Z}=\beta_{0}+\beta_{1} X_{B S I Z E}+\beta_{2} X_{D U A L X}+\beta_{3} X_{I N D E P}+\beta_{4} X_{F I H}+\beta_{5} X_{B D H}+\beta_{6} X_{T B H}+\beta_{7} X_{E M H}+\beta_{8} X_{S C A L E}+\beta_{9} X_{L E V}+\beta_{10} X_{G R O W}+\varepsilon_{i}$

where $Y_{Z}$ denotes the dependent variable, $\beta_{i}$ represents the coefficients to be estimated. Moreover, Table 1 shows the summary of the independent variables. 
Table 1

Definition and measurement of variables

\begin{tabular}{ll}
\hline X BSIZE & Independent variable representing Board Size \\
X_DUAL & Independent variable representing CEO Duality \\
X_INDEP & Independent variable representing Board Independence \\
X_FIH & Independent variable representing Financial Institution Shareholdings \\
X_BDH & Independent variable representing Board of Directors shareholdings \\
X_TBH & Independent variable representing Top ten Blockholder shareholdings \\
X_EMH & Independent variable representing Executive and Manager shareholdings \\
X_SCALE & Independent variable representing the size of the firm \\
X_LEV & Independent variable representing the firm level of leverage \\
X_GROW & Independent variable representing a growth rate of revenue \\
$€ \mathrm{i}$ & This error term variable incorporates alternative influencers of the dependent variable $(\mathrm{Yz})$ other than the stipulated regressors (Xi). \\
\hline
\end{tabular}

\subsection{Independent variables}

This study aims to explore the impacts of board characteristics and ownership structure on R\&D intensity. Consistent with prior studies (e.g., Gentry \& Shen, 2013; Chen \& Miller, 2007; Cohen \& Levinthal, 1990), we measured R\&D intensity (RD) as the percentage of firm R\&D expenses over total revenues during each fiscal year.

\subsection{Dependent variables}

In common with prior studies about board characteristics, board size (BSIZE) is measured as the total number of directors on the board. The duality (DUAL) is about board leadership and power structure, which is dummy coded as 1 when the CEO and the Chairperson of the firm are the same people, as 0 otherwise. The level of board independence is measured in two ways: the percentage of independent directors (INDEP) and the percentage of outside directors (OUTSI) on the board. The percentages of shareholding by financial institutions (FIH), board directors (BDH), top blockholders (TBH), executives, and managers (EMH), were adopted to explore the feature of ownership structure from different perspectives.

\subsection{Control variables}

Based on relevant literature, firm scale (SCALE), level of leverage (LEV), and growth dynamics (GROW) were adopted as control variables.

\section{Empirical results}

Table 2, provides descriptive statistics for the variables used in this research. The statistical summary represents the analyzed data from SPSS in the form of mean, standard deviation, minimum, and maximum. This study includes 1736 firm-year observations of 434 technological firms listed on the Taiwanese Stock Exchange (TWSE) between 2014 and 2017 (4-year observations). Concerning CEO duality, at least $35 \%$ of CEO's fill the Chairman position simultaneously. On average at least $28 \%$ of directors are independent in Taiwanese firms, with a minimum of 0 and a maximum of $66 \%$, indicating that there are still Taiwanese companies that do not appoint independent directors. The average number of directors on the board is 7.4 (with a minimum of 2 and a maximum of 15$)$.

Table 2

Represents the summary of descriptive statistics for all the variables

\begin{tabular}{llllll}
\hline Variable & Observations & Mean & Std. Dev. & Min & Max \\
\hline DUAL & 1736 & .3536866 & .4782511 & 0 & 1 \\
INDEP & 1736 & 28.98106 & 14.71541 & 0 & 66.66667 \\
BSIZE & 1736 & 7.417051 & 1.915214 & 2 & 15 \\
FIH & 1736 & 2.66754 & 3.975648 & 0 & 21.84 \\
BDH & 1736 & 19.69603 & 14.62912 & .05 & 94.56 \\
TBH & 1736 & 20.77208 & 11.31322 & .51 & 75.46 \\
EMH & 1736 & 4.384821 & 5.783061 & 0 & 49.62 \\
GROW & 1736 & 3.858621 & 41.02389 & -91.31 & 974.48 \\
SCALE & 1736 & 6.932027 & .6095086 & 4.268976 & 9.5324 \\
LEV & 1736 & 41.18697 & 17.21019 & .9038369 & 99.76047 \\
\hline
\end{tabular}

Concerning ownership structures, the average Financial Institutional ownership is $2.6 \%$ with a maximum of $21.8 \%$. Board of Directors holds an average of $19.59 \%$ with a maximum of $94.5 \%$. Top Blockholders have an average of $20.77 \%$ and a maximum of $74.6 \%$, while Executive and managers hold an average of $4.3 \%$, and some in companies they have no ownership. Concerning control variables, the average firm is 6.93 billion NTD (New Taiwan Dollars), the average growth is $3.85 \%$, the average debt ratio is $41.18 . \%$ 
Table 3

Model summary for multiple regression

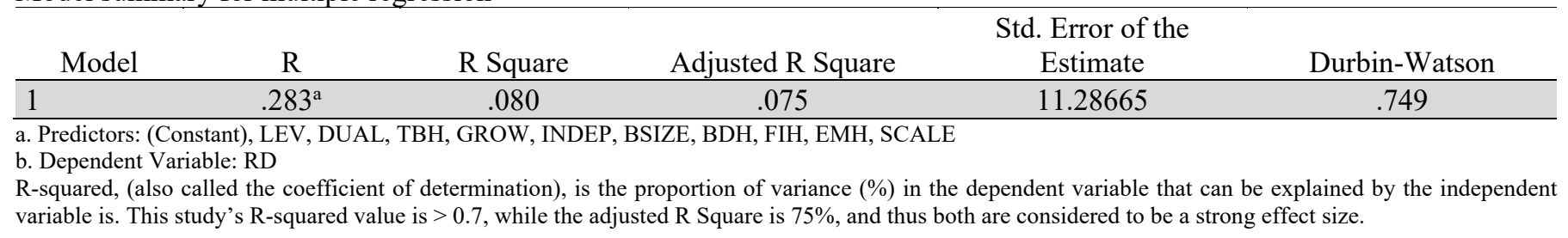

Table 4

ANOVA summary statistics

\begin{tabular}{ccccccc}
\hline & Model & Sum of Squares & df & Mean Square & F & Sig. \\
\hline \multirow{2}{*}{1} & Regression & 19122.059 & 10 & 1912.206 & 15.011 & $.000^{\mathrm{b}}$ \\
\cline { 2 - 7 } & Residual & 219745.266 & 1725 & 127.389 & & \\
\cline { 2 - 7 } & Total & 238867.325 & 1735 & & & \\
\hline
\end{tabular}

a. Dependent Variable: RD

b. Predictors: (Constant), LEV, DUAL, TBH, GROW, INDEP, BSIZE, BDH, FIH, EMH, SCALE

Table 4 reports the ANOVA results from SPSS, which is part of the regression model. ANOVA is a test of the hypothesis that is used to compare means of a continuous variable in two or more independent groups of variables. Here, the focus is on $\mathrm{F}$ statistic and the P-value of the model. This P-value for the F statistic of 15.011 has an overall significance is less than $5 \%$, the model is thus sufficient.

Table 5

Variance Inflation Factor summary

\begin{tabular}{cccc}
\hline Variable & VIF & Variable & VIF \\
\hline DUAL & 1.156 & TBH & 1.091 \\
INDEP & 1.017 & EMH & 1.180 \\
BSIZE & 1.191 & GROW & 1.007 \\
FIH & 1.237 & SCALE & 1.463 \\
BDH & 1.123 & LEV & 1.109 \\
\hline
\end{tabular}

Table 6

Effects of Board Characteristics and Ownership Structures on R\&D Intensity - Full Model

\begin{tabular}{|c|c|c|c|c|}
\hline Research Study Variables & Independent variables & $\begin{array}{c}\text { Board Characteristic } \\
\text { variables effect on } \mathrm{R} \& \mathrm{D} \\
\text { intensity }\end{array}$ & $\begin{array}{c}\text { Ownership Structure } \\
\text { variables effect on } \mathrm{R} \& \mathrm{D} \\
\text { intensity }\end{array}$ & $\begin{array}{c}\text { Board Characteristics and } \\
\text { Ownership Structures } \\
\text { combined effect on R\&D } \\
\text { intensity } \\
\end{array}$ \\
\hline \multirow[t]{3}{*}{ Board Characteristics } & Duality & $\begin{array}{c}-.9698088^{*} \\
0.093\end{array}$ & & $\begin{array}{c}-.8493435 \\
0.163\end{array}$ \\
\hline & Board Independence & $\begin{array}{c}.0558387^{* * * *} \\
0.003\end{array}$ & & $\begin{array}{c}.0555588 * * * \\
0.003\end{array}$ \\
\hline & Board Size & $\begin{array}{c}-.154073 \\
0.310\end{array}$ & & $\begin{array}{c}-.185147 \\
0.231\end{array}$ \\
\hline \multirow{3}{*}{ Ownership Structures } & Board of Directors & & $\begin{array}{c}-.035393 * \\
0.070\end{array}$ & $\begin{array}{c}-.0384964 * * \\
0.050\end{array}$ \\
\hline & Top Blockholders & & $\begin{array}{c}-.0046162 \\
0.853\end{array}$ & $\begin{array}{c}-.0148422 \\
0.553\end{array}$ \\
\hline & Executives \& Managers & & $\begin{array}{c}-.0855446^{*} \\
0.074\end{array}$ & $\begin{array}{c}-.0702063 \\
0.168\end{array}$ \\
\hline Control Variables & Leverage & $\begin{array}{c}-.159037 * * * \\
0.000\end{array}$ & $\begin{array}{c}-.160203^{* * *} \\
0.000\end{array}$ & $\begin{array}{c}-.1595213 * * * \\
0.000\end{array}$ \\
\hline Cons & & 20.08925 & 23.87834 & 23.74911 \\
\hline
\end{tabular}

$* * *, * *, *=$ significance at $1 \%, 5 \%$, and $10 \%$ respectively 
A comprehensive diagnostic check of classical assumptions on the residuals or error terms was conducted, and included normality and multicollinearity assessment, through variance inflation factors (VIF), all models do not appear to have strong multicollinearity problems; in all of the specifications, according to Table 5, we find the study VIF values are all smaller than 1.5.

Table 6 outlines the effects of the independent variables, board characteristics, and ownership structures on the dependent variable, R\& D intensity. This full model incorporates 1736 firm-year observations of 434 technological firms listed on the Taiwanese Stock Exchange (TWSE) between 2014 and 2017 (4-year observations). Columns 1 and 2 represent the research study's Independent and Control variables. Column 3 reflects the relationship coefficient and significance of the board characteristics effect on R\&D intensity, while column 4 shows the relationship coefficient and significance of ownership structures on effect on R\&D intensity. Column 5 outlines the combined board characteristics and Ownership Structure independent variables relationship and significant effects on R\&D intensity.

We find a consistently negative and statistically significant relationship between R\&D intensity in CEO duality (a correlation of -.9698088 at a significance level of 1\%); Board of Directors ownership, (a correlation of -.035393 at a $1 \%$ significance level), and Executive and Managers ownership (a correlation of -.0855446 at a $1 \%$ significance level). Furthermore, the size of the firms and leverage is also negative and significant. There is a strong positive and significant relationship between Board Independence and R\&D intensity (a correlation of .0558387 at the $10 \%$ significance level).

Table 7

Effects of Board Characteristics and Ownership Structures on R\&D Intensity in different Industrial settings - Split Model

\begin{tabular}{|c|c|c|c|c|c|c|}
\hline \multirow[b]{2}{*}{$\begin{array}{l}\text { Board } \\
\text { Characteristics }\end{array}$} & \multicolumn{2}{|c|}{ Grow } & \multicolumn{2}{|c|}{ Scale } & \multicolumn{2}{|c|}{ Leverage } \\
\hline & Negative & Positive & Small & Big & Low & High \\
\hline Duality & $\begin{array}{c}-1.51323 \\
.202\end{array}$ & $\begin{array}{c}-.4569694 \\
0.340\end{array}$ & $\begin{array}{c}-1.639912 \\
0.115\end{array}$ & $\begin{array}{c}-.1208093 \\
0.840\end{array}$ & $\begin{array}{c}-1.435911 \\
0.212\end{array}$ & $\begin{array}{c}.2538661 \\
0.420\end{array}$ \\
\hline Independence & $\begin{array}{c}.0713573^{* *} \\
0.047\end{array}$ & $\begin{array}{c}.0433427^{* * * *} \\
0.003\end{array}$ & $\begin{array}{c}.0653927^{* *} \\
0.036\end{array}$ & $\begin{array}{c}.0356716^{*} \\
0.055\end{array}$ & $\begin{array}{c}.0819265^{* *} \\
0.018\end{array}$ & $\begin{array}{c}.0107089 \\
0.267\end{array}$ \\
\hline Board Size & $\begin{array}{c}-.2519765 \\
0.390\end{array}$ & $\begin{array}{c}-.0755199 \\
0.543\end{array}$ & $\begin{array}{c}-.2514163 \\
0.430\end{array}$ & $\begin{array}{c}-.2252068^{*} \\
0.085\end{array}$ & $\begin{array}{c}-.4408269 \\
0.123\end{array}$ & $\begin{array}{c}.1044907 \\
0.200\end{array}$ \\
\hline \multicolumn{7}{|l|}{$\begin{array}{l}\text { Ownership } \\
\text { Structures }\end{array}$} \\
\hline $\begin{array}{l}\text { Financial } \\
\text { Institutions }\end{array}$ & $\begin{array}{c}.0244168 \\
0.869\end{array}$ & $\begin{array}{c}.640411 \\
0.285\end{array}$ & $\begin{array}{c}.1265295 \\
0.434\end{array}$ & $\begin{array}{c}-.0283953 \\
0.652\end{array}$ & $\begin{array}{c}.0336552 \\
0.814\end{array}$ & $\begin{array}{c}-.0092913 \\
0.810\end{array}$ \\
\hline Board of Directors & $\begin{array}{c}-.0435627 \\
0.256\end{array}$ & $\begin{array}{c}-0.299804 * * \\
0.052\end{array}$ & $\begin{array}{l}.00718 \\
0.844\end{array}$ & $\begin{array}{c}-.0700547 * * * \\
0.000\end{array}$ & $\begin{array}{c}-.0505358 \\
0.167\end{array}$ & $\begin{array}{c}-.0233709 * * \\
0.026\end{array}$ \\
\hline Top Blockholders & $\begin{array}{c}0.139327 \\
0.779\end{array}$ & $\begin{array}{c}-.048054^{* *} \\
0.014\end{array}$ & $\begin{array}{c}.0248097 \\
0.553\end{array}$ & $\begin{array}{c}-.0686876^{* * * *} \\
0.007\end{array}$ & $\begin{array}{c}.0084374 \\
0.860\end{array}$ & $\begin{array}{c}-.0281182 * * \\
0.026\end{array}$ \\
\hline $\begin{array}{l}\text { Executives and } \\
\text { Managers }\end{array}$ & $\begin{array}{c}-.1028539 \\
0.317\end{array}$ & $\begin{array}{c}-.0110717 \\
0.776\end{array}$ & $\begin{array}{c}-.0925023 \\
0.283\end{array}$ & $\begin{array}{c}-.0365189 \\
0.468\end{array}$ & $\begin{array}{c}-.0907217 \\
0.397\end{array}$ & $\begin{array}{c}-.0357242 \\
0.134\end{array}$ \\
\hline Grow & $\begin{array}{c}-.1724998 \\
0.0000\end{array}$ & $\begin{array}{c}.0039181 \\
0.360\end{array}$ & $\begin{array}{c}-.0119709 \\
0.179\end{array}$ & $\begin{array}{c}-.0073357 * * * \\
0.521\end{array}$ & $\begin{array}{c}-.0088797 \\
0.403\end{array}$ & $\begin{array}{c}-.0099126^{* *} \\
0.022\end{array}$ \\
\hline Scale & $\begin{array}{c}-1.491083 \\
0.173\end{array}$ & $\begin{array}{c}-.5717203 \\
0.176\end{array}$ & $\begin{array}{c}-7.57734 * * * \\
0.000\end{array}$ & $\begin{array}{c}-.1511403 \\
0.797\end{array}$ & $\begin{array}{c}-2.040279 * * \\
0.061\end{array}$ & $\begin{array}{c}-.67693 * * \\
0.010\end{array}$ \\
\hline Leverage & $\begin{array}{c}-.189353 \\
0.000\end{array}$ & $\begin{array}{c}-.1258844 * * * \\
0.000\end{array}$ & $\begin{array}{c}-.1969192 * * * \\
0.000\end{array}$ & $\begin{array}{c}-.1330273 * * * \\
0.000\end{array}$ & $\begin{array}{c}-.4615782 * * * \\
0.000\end{array}$ & $\begin{array}{c}-.0453579 * * * \\
0.001\end{array}$ \\
\hline- cons & 22.612 & 14.93635 & 62.82341 & 15.04504 & 36.06644 & 10.73814 \\
\hline
\end{tabular}

$* * *, * *, *=$ significance at the $1 \%, 5 \%$, and $10 \%$ respectively

Table 7 reflects the effects of the independent variables, board characteristics, and ownership structures on the dependent variable, R\& D intensity. This model incorporates 1736 firm-year observations of 434 technological firms listed on the Taiwanese Stock Exchange (TWSE) between 2014 and 2017 (4-year observations). We have spilt the variables and analyzed them according to three different industrial settings, namely, firm scale, level of leverage, and growth dynamics.

From a Board characteristics perspective, It is interesting to note that once again, and in line with the result as indicated in table 6, Board independence has a positive and significant relationship in firms that are growing and shrinking, in large and small firms, and in firms that exhibit low levels of leverage. There is a negative and significant relationship between the size of the board and R\&D investment in large firms. Furthermore, these results reveal that the Board of directors' ownership and top Blockholders ownership are negative and significantly related to R\&D intensity for large firms that are growing and are highly leveraged. 
Table 8

Correlation Matrix

\begin{tabular}{|c|c|c|c|c|c|c|c|c|c|c|}
\hline & DUAL & INDEP & BSIZE & FCH & BDH & TBH & EMH & GROW & SCALE & LEV \\
\hline BSIZE & -0.1460 & 0.0151 & 1.0000 & & & & & & & \\
\hline BDH & -0.0858 & -0.0299 & -0.0266 & -0.1217 & 1.0000 & & & & & \\
\hline TBH & -0.0020 & 0.1013 & -0.0653 & 0.2013 & -0.2103 & 1.0000 & & & & \\
\hline EMH & 0.3281 & -0.0274 & -0.2183 & -0.1446 & 0.0567 & 0.0238 & 1.0000 & & & \\
\hline LEV & -0.0023 & -0.0023 & 0.0410 & 0.0651 & -0.0999 & 0.0135 & -0.0154 & 0.0427 & 0.2889 & 1.0000 \\
\hline
\end{tabular}

Table 8 reports the results of the Pearson correlation matrix amongst all the independent variables used in the regressions for the full sample over the period 2014-2017. The correlation coefficients between all independent variables are small (with a maximum of 0.5357 ), suggesting no multicollinearity problem.

\section{Conclusion}

This study investigates the influence of board characteristics and ownership structures on firm R\&D intensity by assessing 1736 firm-year observations of 434 technological firms listed on the Taiwanese Stock Exchange (TWSE) between 2014 and 2017. The examined board characteristics include CEO Duality, Board independence, and Board size. Owner structures relating to Top Blockholders, Board of Directors, Financial Companies, and Executive \& Management have been utilized for analysis. A finding of particular interests reveals that Board Independence has a positive and strong significant relationship to R\&D intensity. Negative and significant relationships are shown for CEO duality, Board of directors, Executive \& Managers, and top Blockholders ownership in the full sample and after the sample has been split. The results are consistent with the predictions of the entrenchment theory. In business environments like Taiwan, there may be a tendency to implement a more "conservative" strategy avoiding risky investments with uncertain payoffs. Additionally, ownership concentration may encourage entrenchment behavior on the part of the controlling shareholders, the reason being that there is no need to monitor management, resulting in the non-pursuance of strategies directed at long term value creation. Moreover, the board of directors may be strongly influenced by the owners in regards to decision making. This research contributes to the extant literature and extends the current knowledge about the relationship between Board characteristics, ownership structures, and R\&D intensity from a Taiwanese business perspective.

\section{Practical Implications for Asian Business}

The outcomes of this research offer valuable and significant insights which may advance firm policy formulation, by providing Taiwanese business owners, executive management, and shareholders with empirically tested outcomes, and recommendations for optimizing their approach to R\&D strategic decision orientation. The impact of corporate governance mechanisms on firm $R \& D$ is a stream of inquiry that is gaining traction. Researchers have addressed several dimensions within this realm, and contribution evidence has been diverse. Studies have predominantly evaluated the influence of specific dimensions of corporate governance on firm R\&D. Moreover, these studies recurrently circumscribe to contexts predominantly in the United States and Europe. Global corporate governance systems are disparate in nature, and this heterogeneity presents an opportunity to address how these issues may emerge in an Asian context. Unlike the vast quantities of studies undertaken in western-developed countries, this research analyzes corporate governance mechanisms' impact on R\&D strategic decisions in a newly industrialized economy, Taiwan. Secondly, the results of this study could be compared with findings emerging from developed countries, thus providing the impetus for gap closure between developed and developing contexts. Thirdly, whereas, several studies have utilized a single indicator of R\&D decision making, this study applies both corporate governance mechanisms and ownership structures accordingly. Fourthly, this study goes beyond the traditional theoretical approach to corporate governance, as it incorporates principles pertinent to the agency-, resource dependence-, shareholder- and stewardship- theories, Business Research and Development (R\&D), includes innovative strategic endeavors, as well as the inspective processes, organizations undertake to advance existing products and procedures. These undertakings, which are financed and methodologically structured by companies, constitute a core component for sustainable growth.

Extant literature exploring the antecedents and outcomes of these R\&D initiatives have been vastly explored over the past 50 years, and this growing field of research continues to attract researchers and practitioners due to the significant associative contributions thereof. Numerous studies have been conducted to understand the facilitators of corporate entrepreneurialism and innovation. A significant influence of these organizational imperatives is research and development expenses. These expenses support organizations to develop competencies, thus influencing innovative capabilities. Consequently, this premise highly 
influences R\&D intensive industries, where R\&D appropriation, expense control, and advancing efficiencies, are all prerequisites for firm durability. The technological industry in Taiwan is a substantial contributor to economic opportunities, thus a study of factors that impact decision making thereon are significant and fundamental. This research offers insight into which strategic decisions relating to corporate governance mechanisms and ownership structures could be implemented for optimal competitiveness and sustainability. Additionally, industrial and commercial contexts regarding the strategic and sustainability value of R\&D have also been defined. More specifically, from a policy perspective antecedent of R\&D environments relative to investment thereof have been explored. R\&D benefits can be further supported by the associated absorptive capability and critical learning opportunities. Other advantages include R\&D's augmentation of firm productivity and R\&D's contribution to the maintenance and enrichment of organizational competitive advantages which include sustainable accomplishment. These factors are also predominant in industries that are R\&D intensive. Despite R\&D's importance and significance as delineated above, investment in R\&D constitutes a vulnerability. This is a consequence of high failure rates, intensive sunken costs, as well as time, profit latency, and volatile appropriability. Furthermore, R\&D strategic decision making is also influenced by information asymmetry. This gap in the available information levels is a consequence of company confidentiality policies, as well as the expertise of inside managers. Hence, shareholders and creditors are challenged to assess R\&D contributions accordingly. R\&D information asymmetry, therefore, increases the financing expenses for projects that exhibit extended durations as well as indeterminate results. Beyond these costs, significant financial restrictions are imminent. The structuring of corporate governance mechanisms, and subsequent contribution to firm policy for the improvement of shareholders' protection, as well as profit maximization, are key corporate imperatives, and it is in this light that this field of research seeks to contribute within a Taiwanese context.

\section{References}

Ashwin, A. S., Krishnan, R. T., \& George, R. (2016). Board characteristics, financial slack, and R\&D investments: An empirical analysis of the Indian pharmaceutical industry. International Studies of Management \& Organization, 46(1), 8-23.

Baysinger, B., \& Hoskisson, R. E. (1990). The composition of boards of directors and strategic control: effects on corporate strategy. Academy of Management Review, 15, 72-87.

Baysinger, B. D., Kosnik, R. D., \& Turk, T. A. (1991). Effects of the board and ownership structure on corporate R\&D strategy. Academy of Management Journal, 34(1), 205-214.

Boyd, B. (1994). Board control and CEO compensation. Strategic Management Journal, 15, 335-44.

Chen, H. L., \& Hsu, W. T. (2009). Family ownership, board independence, and R\&D investment. Family Business Review, 22(4), 347-362.

Chen, W. R., \& Miller, K. D. (2007). Situational and institutional determinants of firms' R\&D search intensity. Strategic Management Journal, 28(4) 369-381.

Chung, K., Wright, P., \& Media, B. (2003). Corporate governance and market valuation of capital and R\&D investments. Review of Financial Economics, 12, 161-172.

Cohen, W. M., \& Levinthal, D. A. (1990). Absorptive capacity: A new perspective on learning and innovation. Administrative Science Quarterly, 35(1), 128-152.

Dalziel, T., White, R. E., \& Arthurs, J. D. (2011). Principal costs in initial public offerings. Journal of Management Studies, 48(6), 1346-1364.

Demsetz, H., \& Lehn, K. (1985). The structure of corporate ownership: Causes and consequences. Journal of Political Economy, 93, $1155-1177$.

Eisenhardt, K. M. (1989). Agency theory: An assessment and review. The Academy of Management Review, 14(1), 57-74.

Fama, E. F., \& Jensen, M. C. (1983). Agency problem and residual claims. Journal of Law and Economics, 26(2), 327-349.

Francis, J., \& Smith, A. (1995). Agency costs and innovation. Some empirical evidence. Journal of Accounting and Economics, 19, 383-409.

Driver, C., \& Guedes M. J. C. (2012). Research and development, cash flow, agency, and governance: UK large companies. Research Policy, 41, 1565-1577.

Graves, S. (1988). Institutional ownership and corporate R\&D in the computer industry. Academy of Management Journal, 31, 417-427.

Grinblatt, M., \& Titman, S. (1998). Financial Markets and Corporate Strategy. Boston, MA: Irwin/McGraw Hill.

Gugler, K. (2003). Corporate governance, dividend layout policy, and the interrelation between dividends, R\&D, and capital investment. Journal of Banking \& Finance, 27, 1297-1321

Hernandez, A. B., Camelo, C., \& Valle, R. (2010). The effects of boards of directors on R\&D investments: the case of Spain. International Journal of Human Resources Development and Management, 10(2), 152-165.

Hill, C. W., \& Snell, S. (1988). External control, corporate strategy, and firm performance in research-intensive industries. Strategic Management Journal, 9, 577-590.

Holderness, C. G., \& Sheehan, D. P. (1988). The role of majority shareholders in publicly held corporations. Journal of Financial Economics, 20, 317-346. 
Hoskisson, R. E., Hitt, M. A., Johnson, R. A., \& Grossman, W. (2002). Conflicting voices: The effects of institutional ownership heterogeneity and internal governance on corporate innovation strategies. Academy of Management Journal, 45, 697-716.

Hoskisson, R. E., Johnson, R. A., \& Hill, C. A. (1993). Managerial incentives and investment in R\&D in large multiproduct firms. Organization Science, 4, 325-341.

Hosono, K., Tomiyama, M., \& Miyagawa, T. (2004). Corporate governance and research and development: Evidence from Japan. Economics of Innovation and New Technologies, 13, 141-164.

Jensen, M. C. (1993). The modern industrial revolution, exit and the failure of internal control systems. Journal of Finance, 48(3), 831-881.

Jensen, Mi. C., \& Murphy, K. J. (1990). CEO Incentives: It's Not How Much You Pay, But How. Michael C. Jensen, Foundations of organizational strategy, Harvard University Press, 1998; Harvard Business Review, 3(May-June), 1990,

Jensen, M. C., \& Meckling, W. H. (1976). Theory of the firm: Managerial behavior, Agency costs, and ownership Structure. Journal of Financial Economics, 3(October 1976), 305-60.

Jones, E., \& Danbolt, J. (2003). R\&D Project Announcements and the Impact of Ownership Structure. Applied Economics Letters, 10,933-936.

Kochhar, R., \& David, P. (1996). Institutional investors and firm innovation: A test of competing hypothesis. Strategic Management Journal, 17, 73-84.

Kor, Y.Y. (2006). Direct and interaction effects of the top management team and board compositions on R\&D investment strategy. Strategic Management Journal, 27(11), 1081-1110

Kroszner, R., \& Strahan, A. (2001). Bankers on boards: Monitoring, conflicts of interests, and lender liability. Journal of Financial Economics, 62, 415-452.

Lee, P. G. (2005). A Comparison of Ownership Structures and Innovations of US and Japanese Firms. Managerial and Decision Economics, 26, 39-50.

Lee, P. G., \& O'Neil, H. M. (2003) Ownership Structures and R\&D Investments of US and Japanese Firms: Agency and Stewardship Perspectives. Academy of Management Journal, 46, 212-225.

Lehn, K.M., \& Zhao, M. (2006). CEO turnover after acquisitions: Are bad bidders fired. Journal of Finance, 61(4), $1759-1811$.

Lu, J., \& Wang, W. (2015). Board independence and corporate investments. Review of Financial Economics, $24,52-64$.

Mallette, P., \& Fowler, K. L. (1992). Effects of board composition and stock ownership on the adoption of poison pills. Academy of Management Journal, 35(5), 1010-1035.

May, D. O. (1995). Do managerial motives influence firm risk reduction strategies? Journal of Finance, 50, $1291-1309$.

Pathan, S., \& Faff, R. (2013). Does board structure in banks really affect their performance? Journal of Banking \& Finance, $37(5)$, 1573-1589.

Petersen, M. A., \& Rajan, R. G. (1994) The benefits of lending relationships: Evidence from small business data. Journal of Finance, 49, 3-37

Pfeffer, J. (1972). Size and composition of corporate boards of directors: The organization and its environment. Administrative Science Quarterly, 17, 218-228.

Platt, H., \& Platt, M. (2012). Corporate board attributes and bankruptcy. Journal of Business Research, 65(8), $1139-1143$.

Wahal, S., \& Mcconnell, J. J. (2000). Do institutional investors exacerbate managerial myopia?. Journal of Corporate Finance, 6, 307-329.

Wang, T., \& Hsu, C. (2013). Board composition and operational risk events of financial institutions. Journal of Banking \& Finance, 37(6), 2042-2051.

Westphal, J. D. (1999). Collaboration in the boardroom: Behavioral and performance consequences of CEO-board social ties. Academy of Management Journal, 42, 7-24.

Zahra, S. A., \& Pearce, J. A. (1989). Boards of directors and corporate financial performance: A review and integrative model. Journal of Management, 15(2), 291-334.

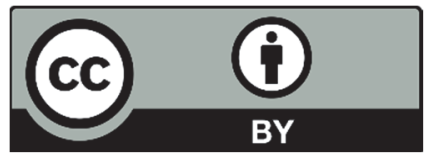

(C) 2021 by the authors; licensee Growing Science, Canada. This is an open access article distributed under the terms and conditions of the Creative Commons Attribution (CC-BY) license (http://creativecommons.org/licenses/by/4.0/). 